\title{
Characterization of crude oil-degrading bacteria in a crude oil-contaminated and uncontaminated site in Kuwait
}

\author{
A. Hassan, Z. Taqi, C. Obuekwe \& E. Al-Saleh \\ Department of Biological Science, Kuwait University, Kuwait
}

\begin{abstract}
The planning of cities must insure a balance between human consumption and natural resources that should be preserved and if needed should be used minimally and efficiently following plans of sustainability. The current study investigated the possibility of recycling natural waste product "plants leaves" that usually fall off, are collected, dumped and burnt. In counties like Kuwait where crude oil constitutes a major pollutant and the environment is hostile for microbial activity rendering bioremediation to be a trivial option. Thus, in the present study, the leaves of Conocarpus and Tamarix were used to enrich the low organic content soils that showed the potential of soil supplementation with organic matter to enhance the growth and activity of soil indigenous microbiota. The amendments of soils with $20 \mathrm{mg} \mathrm{g}^{-1}$ soil significantly increased the counts of crude oil-degrading bacteria in crude oil-contaminated and uncontaminated soils to $999.4 \times 10^{-3} \mathrm{CFU} \mathrm{g}{ }^{-1}$ and $358.8 \times 10^{-3} \mathrm{CFU} \mathrm{g} \mathrm{g}^{-1}$ soil, respectively. The identification of isolated bacteria revealed the dominance of the genus Microbacterium (39.6\%), Sphingopyxis soli (19.3\%), and Bordetella petrii $(19.6 \%)$ in unamended, Conocarpus-amended and Tamarix-amended contaminated soils, respectively. The 16S rRNA analyses showed the high diversity of isolated bacteria. Also, the diversity of the majority of isolated bacteria decreased after soil amendments with plant-derived material. Therefore, the recycling of plant-derived materials could be an excellent option under conditions tested and confirm the commandments of sustainable planning.

Keywords: bioremediation, Conocarpus, Tamarix, crude oil-degrading bacteria, Microbacterium, Sphingopyxis, $16 \mathrm{~S}$ rDNA, amendments.
\end{abstract}




\section{Introduction}

Pollution is not just the addition of substances that damage or kill organisms; it is any man-made impact that increases the risk of damage to a natural system (Moss [10]). Pollutants and contaminants are produced yearly through natural and anthropogenic activities such as industrial activities, agricultural practices, and waste disposal systems. High level, medium-level, and low-level wastes in solid, liquid, or gaseous forms are released into the environment at separate intervals or on a continuous basis (Balonov [4]). Several proposals were made by companies for remediation of heavily polluted soils after the oil lakes are drained of liquid crude oil. These included conversion of oily soil to road base material or a topping layer for car parks and roads after mixing with aggregate or consolidation agents. Other methods include containment in large burial sites, incineration, biological methods, absorption methods, soil washing methods, air stripping, thermal treatment (Lefebvre and Moletta [9]) and vacuum extraction and separation by centrifugation. However, physical and chemical approaches are expensive and byproducts may cause secondary contamination of soil and water resulting in the need for additional post-treatments. As such, there is a widespread interest in bioremediation for the complete mineralization of hydrocarbons to carbon dioxide and water. Bioremediation is a cost effective method and provides in situ remediation without disturbing native ecosystems (Bragg et al. [6]). Generally speaking, several bioremedial approaches have been applied to contaminated soils to reduce impacts of crude oil pollution. These include stimulation of indigenous oil-degrading microbiota by the addition of fertilizers high in nitrogen and phosphorus and/or oxygen; a technology known as biostimulation; seeding of the oil-fouled areas with hydrocarbon-degrading microorganisms; and application of surfactants to the oil-contaminated zone (Edwards et al. [8]). In strictly aerobic conditions, adding nutrient at an adequate rate is sufficient for the biodegradation of saturated hydrocarbons. It was suggested that excess of amendment reduces the assimilation of hydrocarbons. Also, the extent of assimilation of aromatics and hexane insoluble molecules are not increased with high inputs of nutrient as compared to natural attenuation. There are three strategies of nutrient application that are generally used for bioremediation purposes. The first strategy encompasses the addition of soluble mineral nutrients to soil. The second strategy involves the addition of organic nutrient formulations. The third strategy comprises the addition of slow-release inorganic fertilizers (SRIFs) to soil or sediments (Xu et al. [12]). In addition, during the past years, composting strategies have been introduced in the bioremediation of contaminated soils by adding high amounts of agro-industrial wastes (pine sawdust, sugarcane bagasse, wheat straw, compost, etc.) for the removal of organic pollutants (Civilini et al. [7]). However, the cost of applying the aforementioned bioremediation technologies created a need for cheaper methods. In order to overcome the problem of high cost of added nutrients to soil, the addition of plant leaves (litter) especially of local dominant plants in Kuwait such as Tamarix aphylla and Conocarpus spp. to soil was proposed. Therefore, the aim of the present investigation was to investigate the potential for 
enhancing the rates of crude oil bioremediation in crude oil-contaminated soil via the addition of organic materials (as nutrient sources) derived from two local plants Conocarpus and Tamarix spp.

\section{Materials and methods}

\subsection{Collection, preparation and characterization of plant-derived material}

Leaves of Tamarix aphylla and Conocarpus were collected, washed thoroughly three times with sterile water, air dried, and ground then stored at $-20^{\circ} \mathrm{C}$.

\subsection{Collection and characterization of soil samples}

The effects of nutrients addition on the rate of crude oil degradation were studied using crude oil contaminated and uncontaminated soils collected from AlSabreia oil field, north of Kuwait. Soil samples were collected in sterile plastic containers, kept at $4^{\circ} \mathrm{C}$ and transported immediately to the laboratory for treatment. Soil samples were sieved $(2 \mathrm{~mm})$ and stored for two weeks at $4^{\circ} \mathrm{C}$ for stabilization. The total carbon, hydrogen, nitrogen and sulfur in soil samples were determined using standard methods (Alef [1]).

\subsection{Amendments of soil with plant-derived materials}

Prior to the onset of the biodegradation/mineralization experiments, soil samples were amended with varying amounts of prepared organic supplements $(20 \mathrm{mg}$, $60 \mathrm{mg}$ and $100 \mathrm{mg} \mathrm{g}^{-1}$ soil) to provide known amounts of nutrients. Then, soil samples $(50 \mathrm{~g})$ were transferred to sterile reaction glass bottles $(250 \mathrm{ml})$. The water content was adjusted to $30 \%$, the contents of the reaction bottles were mixed gently for $10 \mathrm{~min}$ and incubated at $25^{\circ} \mathrm{C}$. The bottles were used for the mineralization and biodegradation experiments.

\subsection{Determination of biodegradation potentials of soil microbiota}

The rate of crude oil biodegradation was determined using gas chromatography (GC). Soil samples (50g) were transferred to screw-capped bottles (Duran) followed by the addition of organic supplement $\left(20 \mathrm{mg}, 60 \mathrm{mg}\right.$ and $100 \mathrm{mg} \mathrm{g}^{-1}$ soil). Water content was adjusted to $30 \%$ and bottle contents were mixed for $10 \mathrm{~min}$ and incubated at $25^{\circ} \mathrm{C}$. After one month of incubation, residual crude oil in three flasks was extracted three times with equal volumes of pentane at $5^{\circ} \mathrm{C}$. All pentane extracts were pooled for crude oil analysis.

\subsection{Enumeration, isolation and identification of bacteria in soil}

The culturable total heterotrophic (THB) and crude oil-degrading bacteria in contaminated and uncontaminated soils were counted before and after the amendments experiments in order to study the effects of nutrients amendments on the THB and crude oil-degrading bacterial populations. Bacteria in soil were counted using standard plate dilution method. Three portions from soil samples 
were pooled, thoroughly mixed, and passed through a sterile sieve (mesh size, $2 \mathrm{~mm}$ ). Ten grams (wet weight) of soil was suspended in $40 \mathrm{ml}$ of $50 \mathrm{mM}$ phosphate buffer $(\mathrm{pH}$ 7.2) and vortexed for 1 minute at low speed. Aliquots $(100 \mu \mathrm{l})$ in direct and $10^{-1}-10^{-6}$ dilutions were spread on Hutner's minimal agar plates and incubated under crude oil vapor in a desiccator at $25^{\circ} \mathrm{C}$ for up to 21 days. Grown colonies were counted and the numbers of crude oil-degrading bacteria $\mathrm{g}^{-1}$ soil were calculated and expressed as Colony Forming Unit (CFU) $\mathrm{g}^{-1}$ soil.

\subsection{Identification and fingerprinting of isolated crude oil-degrading bacteria by 16S-RFLP}

The isolated bacteria were identified by sequencing of the 16S rDNA and fingerprinted using 16S-RFLP following previous methods (Al-Saleh and Obuekwe [3]).

\section{Results}

The total amounts of carbon, hydrogen, nitrogen and sulfur of soil samples were determined. As can be seen in Table 1, the total amounts of hydrogen, nitrogen, sulfur and carbon were significantly higher $(\mathrm{P}<0.05)$ in the contaminated soil $(2.027 \%, 0.050 \%, 0.419 \%$ and $14.32 \%$, respectively) compared to those in the uncontaminated soil samples $(0.245 \%, 0.020 \%, 0.034 \%$ and $0.040 \%$, respectively).

Table 1: Amount of total carbon, hydrogen, nitrogen and sulfur in soil samples.

\begin{tabular}{|c|c|c|}
\hline Elements & $\begin{array}{c}\text { Uncontaminated soil } \\
(\%)\end{array}$ & $\begin{array}{c}\text { Contaminated soil } \\
(\%)\end{array}$ \\
\hline Hydrogen & $0.245 \pm 0.02$ & $2.027 \pm 0.21$ \\
\hline Nitrogen & $0.020 \pm 0.001$ & $0.050 \pm 0.001$ \\
\hline Sulfur & $0.034 \pm 0.001$ & $0.419 \pm 0.03$ \\
\hline Carbon: & $1.830 \pm 0.15$ & $14.32 \pm 0.32$ \\
\hline Inorganic carbon & $0.040 \pm 0.001$ & $0.220 \pm 0.02$ \\
\hline Organic carbon & $1.790 \pm 0.14$ & $14.10 \pm 0.33$ \\
\hline
\end{tabular}

The mineralization studies to assess the effects of the addition of plantderived material on the mineralization of crude oil in soil (Tables 2 and 3) were conducted and the results showed that the addition of 20,60 and $100 \mathrm{mg}$ Conocarpus-derived material significantly $(\mathrm{P}<0.05)$ increased the amounts of carbon dioxide evolution by the microbiota of the uncontaminated soil (61992, 21060 and $6669 \mu \mathrm{g}$ carbon dioxide, respectively). Furthermore, the addition of crude oil $\left(4.0 \mu \mathrm{l}\right.$ crude oil $\mathrm{g}^{-1}$ soil) in presence of Conocarpus-derived material (20, 60 and $100 \mathrm{mg} \mathrm{g}^{-1}$ soil) resulted in additional increase in the amounts of 
carbon dioxide evolution in the uncontaminated (68900, 22572 and $6850 \mu \mathrm{g}$ carbon dioxide, respectively) soil samples (Table 2). Moreover, the addition of Tamarix-derived materials to soil samples resulted in similar observations (Table 3). However, the addition of Conocarpus-derived material to soils in presence/absence of crude oil resulted in significantly higher $(\mathrm{P}<0.05)$ amounts of carbon dioxide evolution than that determined when Tamarix-derived materials were added to soil.

Table 2: $\quad$ Effects of the addition of Conocarpus-derived material and crude oil on the evolution of carbon dioxide by soil microbiota.

\begin{tabular}{|c|c|c|}
\hline \multirow{2}{*}{\begin{tabular}{c} 
Amount of $\begin{array}{c}\text { Conocarpus-derived material } \\
(\mathrm{mg} / \mathrm{g} \text { soil })\end{array}$ \\
\cline { 2 - 3 }
\end{tabular}} & \multicolumn{2}{|c|}{$\begin{array}{c}\text { Carbon dioxide evolution } \\
(\mu \mathrm{g})\end{array}$} \\
\hline Non & 2700 & $\begin{array}{c}\text { Conocarpus } \text { and } \\
\text { crude oil }\end{array}$ \\
\hline 20 & 61992 & 68900 \\
\hline 60 & 21060 & 22572 \\
\hline 100 & 6669 & 6850 \\
\hline
\end{tabular}

Equal amounts of soil $(50 \mathrm{~g})$, water $\left(0.4 \mathrm{ml} \mathrm{g}^{-1}\right.$ soil $)$ and crude oil $\left(4.0 \mu \mathrm{g} \mathrm{g}^{-1}\right.$ soil) were added to reaction flasks.

Table 3: $\quad$ Effects of the addition of Tamarix-derived material and crude oil on the evolution of carbon dioxide by uncontaminated soil microbiota.

\begin{tabular}{|c|c|c|}
\hline \multirow{2}{*}{$\begin{array}{l}\text { Amount of Tamarix-derived material } \\
\text { (mg/g soil) }\end{array}$} & \multicolumn{2}{|c|}{$\begin{array}{l}\text { Carbon dioxide evolution } \\
(\mu \mathrm{g})\end{array}$} \\
\hline & Tamarix & Tamarix and crude oil \\
\hline Non & 2700 & 2832 \\
\hline 20 & 27675 & 29977 \\
\hline 60 & 7209 & 7529 \\
\hline 100 & 6939 & 7126 \\
\hline
\end{tabular}

Equal amounts of soil $(50 \mathrm{~g})$ and water $\left(0.4 \mathrm{ml} \mathrm{g}^{-1}\right.$ soil $)$ and crude oil $\left(4.0 \mu \mathrm{g} \mathrm{g}^{-1}\right.$ soil $)$ were added to reaction flasks.

The potential encouragement of crude oil utilization by soil microbiota due to the addition of plant-derived materials was assessed by using gas chromatography method to determine the residual amounts of crude oil in soil. As presented in Table 4, the addition of 20 and $60 \mathrm{mg} \mathrm{g}^{-1}$ soil of Conocarpusderived material to soil in the presence of crude oil ( $4.0 \mu \mathrm{g} \mathrm{g}^{-1}$ soil) significantly 
$(\mathrm{P}<0.05)$ increased the amounts of crude oil biodegradation by the microbiota of uncontaminated (75.2\% and $66.8 \%$, respectively) soil. In addition, , the addition of 20 and $60 \mathrm{mg} \mathrm{g}^{-1}$ soil of Tamarix-derived material to soil in the presence of crude oil (4.0 $\mu \mathrm{g} \mathrm{g}^{-1}$ soil) resulted in analogous observations (Table 4). Nonetheless, the addition of $100 \mathrm{mg} \mathrm{g}^{-1}$ soil of Conocarpus- and Tamarixderived material to soil in the presence of crude oil $\left(4.0 \mu \mathrm{lg}^{-1}\right.$ soil) decreased the potentials of crude oil biodegradation by soil microbiota.

Table 4: $\quad$ Biodegradation of crude oil in presence of plant-derived materials in uncontaminated soil.

\begin{tabular}{|c|c|c|}
\hline \multirow{2}{*}{$\begin{array}{c}\text { Amount of plant-derived material } \\
(\mathrm{mg} / \mathrm{g} \text { soil) }\end{array}$} & \multicolumn{2}{|c|}{$\begin{array}{c}\text { Biodegradation of crude oil } \\
(\%)\end{array}$} \\
\cline { 2 - 3 } & Conocarpus & Tamarix \\
\hline Non & 42.5 & 42.5 \\
\hline 20 & 75.2 & 60.1 \\
\hline 60 & 66.8 & 49.4 \\
\hline 100 & 43.7 & 40.2 \\
\hline
\end{tabular}

Equal amounts of soil $(50 \mathrm{~g})$, water $\left(0.4 \mathrm{ml} \mathrm{g}^{-1}\right.$ soil $)$ and crude oil $\left(4.0 \mu \mathrm{g} \mathrm{g}^{-1}\right.$ soil $)$ were added to reaction flasks. The amounts of crude oil were determined by gas chromatography.

The occurrences of the total heterotrophic and crude oil-degrading bacteria in the crude oil-contaminated and uncontaminated soil samples were determined using plate-dilution method and the results are presented in Table 5. The counts of the total heterotrophic bacteria in contaminated soil samples $\left(13.15 \times 10^{3}\right.$ to $29.85 \times 10^{5} \mathrm{CFU} \mathrm{g}^{-1}$ soil) before and after the addition of plant-derived materials were significantly higher $(\mathrm{P}<0.05)$ than that determined in uncontaminated soil samples $\left(10.12 \times 10^{3}\right.$ to $22.96 \times 10^{5} \mathrm{CFU} \mathrm{g}^{-1}$ soil). The counts of crude oildegrading bacteria in unamended contaminated $\left(9.75 \times 103 \mathrm{CFU} \mathrm{g}^{-1}\right.$ soil) and uncontaminated $\left(3.51 \times 10^{3} \mathrm{CFU} \mathrm{g}^{-1}\right.$ soil) soil samples were lower than the counts of crude oil-degrading bacteria in amended contaminated $\left(2.123 \times 10^{5}\right.$ to $22.38 \times 10^{5} \mathrm{CFU} \mathrm{g}^{-1}$ soil) and uncontaminated $\left(61.25 \times 10^{3}\right.$ to $80.58 \times 10^{4} \mathrm{CFU}$ $\mathrm{g}^{-1}$ soil) soil samples. Additionally, the increases in the counts of the crude oildegrading bacteria in soils amended with Conocarpus-derived material were significantly higher $(\mathrm{P}<0.05)$ than those in soils amended with Tamarix-derived material (Table 5). Furthermore, the molecular identification of crude oildegrading bacteria in the contaminated soil revealed the dominance of the genus Microbacterium (39.6\%), Sphingopyxis soli (19.3\%), and Bordetella petrii $(19.6 \%)$ in unamended, Conocarpus-amended and Tamarix-amended contaminated soils, respectively. The $16 \mathrm{~S}$ rRNA analyses of isolated crude oildegrading bacteria showed the high diversity of isolated bacteria from the contaminated soil. In addition, the diversity of the majority of isolated bacteria decreased after soil amendments with plant-derived material (Table 6). 
Table 5: Counts of total heterotrophic and crude oil-degrading bacteria in soil.

\begin{tabular}{|c|c|c|}
\hline Bacteria & $\begin{array}{c}\text { Uncontaminated } \\
\text { soil } \\
\left.\text { (CFU g g }^{-1} \text { soil }\right)^{*}\end{array}$ & $\begin{array}{c}\text { Contaminated } \\
\text { soil } \\
\left(\mathrm{CFU} \mathrm{g}^{-1} \text { soil }\right)^{*}\end{array}$ \\
\hline \multicolumn{3}{|l|}{$\underline{\text { Total heterotrophic bacteria }}$} \\
\hline Before the commencement of all soil experiments & $10.12 \pm 0.12$ & $13.15 \pm 0.11$ \\
\hline $\begin{array}{l}\text { After the end of control experiments (no plant material } \\
\text { was added) }\end{array}$ & $450.6 \pm 2.33$ & $585.2 \pm 2.39$ \\
\hline After the end of Tamarix experiments $\quad\left(20 \mathrm{mg} \mathrm{g}^{-1}\right.$ soil $)$ & $1025 \pm 4.55$ & $1332 \pm 5.11$ \\
\hline$\left(60 \mathrm{mg} \mathrm{g}^{-1}\right.$ soil $)$ & $267.7 \pm 3.36$ & $347.1 \pm 3.12$ \\
\hline$\left(100 \mathrm{mg} \mathrm{g}^{-1}\right.$ soil $)$ & $175.5 \pm 1.52$ & $283.7 \pm 3.33$ \\
\hline After the end of Conocarpus experiments (20 $\mathrm{mg} \mathrm{g}^{-1}$ soil) & $2296 \pm 6.11$ & $2985 \pm 2.95$ \\
\hline (60 $\mathrm{mg} \mathrm{g}^{-1}$ soil) & $780.4 \pm 3.14$ & $1014 \pm 4.35$ \\
\hline$\left(100 \mathrm{mg} \mathrm{g}^{-1}\right.$ soil) & $585.4 \pm 2.46$ & $870.6 \pm 4.13$ \\
\hline \multicolumn{3}{|l|}{ Crude oil-degrading bacteria } \\
\hline Before the commencement of all soil experiments & $3.510 \pm 0.09$ & $9.750 \pm 0.11$ \\
\hline $\begin{array}{l}\text { After the end of control experiments (no plant material } \\
\text { was added) }\end{array}$ & $157.5 \pm 1.61$ & $438.8 \pm 2.14$ \\
\hline After the end of Tamarix experiments $\quad\left(20 \mathrm{mg} \mathrm{g}^{-1}\right.$ soil $)$ & $358.8 \pm 3.24$ & $999.4 \pm 4.21$ \\
\hline$\left(60 \mathrm{mg} \mathrm{g}^{-1}\right.$ soil $)$ & $93.45 \pm 1.12$ & $260.3 \pm 2.96$ \\
\hline$\left(100 \mathrm{mg} \mathrm{g}^{-1}\right.$ soil) & $61.25 \pm 0.93$ & $212.3 \pm 2.23$ \\
\hline After the end of Conocarpus experiments (20 $\mathrm{mg} \mathrm{g}^{-1}$ soil) & $805.8 \pm 3.78$ & $2238 \pm 6.52$ \\
\hline$\left(60 \mathrm{mg} \mathrm{g}^{-1}\right.$ soil $)$ & $273.7 \pm 2.88$ & $745.5 \pm 3.35$ \\
\hline$\left(100 \mathrm{mg} \mathrm{g}^{-1}\right.$ soil) & $204.8 \pm 2.36$ & $652.5 \pm 2.67$ \\
\hline
\end{tabular}

*Bacterial counts determined (CFU g ${ }^{-1}$ soil $\left.x 1000\right)$. 
Table 6: Identity and number of some isolates of crude oil-degrading bacteria isolated from un-amended and amended contaminated soil with Conocarpus- and Tamarix-derived material.

\begin{tabular}{|c|c|c|c|}
\hline \multirow{2}{*}{ Identity } & \multicolumn{3}{|c|}{ Number of isolated bacteria } \\
\cline { 2 - 4 } & Un-amended soil & $\begin{array}{c}\text { Conocarpus-amended } \\
\text { soil }\end{array}$ & $\begin{array}{c}\text { Tamarix-amended } \\
\text { soil }\end{array}$ \\
\hline $\begin{array}{c}\text { Microbacterium } \\
\text { spp. }\end{array}$ & 21 & 8 & 11 \\
\hline Xanthomonas spp. & 9 & 1 & 4 \\
\hline $\begin{array}{c}\text { Brevundimonas } \\
\text { spp. }\end{array}$ & 8 & 9 & 5 \\
\hline $\begin{array}{c}\text { Stenotrophomonas } \\
\text { spp. }\end{array}$ & 5 & 2 & 0 \\
\hline $\begin{array}{c}\text { Achromobacter } \\
\text { spp. }\end{array}$ & 2 & 0 & 0 \\
\hline Bacillus spp. & 1 & 0 & 4 \\
\hline
\end{tabular}

\section{Discussion}

The significantly $(\mathrm{P}<0.05)$ higher values of total inorganic and organic carbon determined in the crude oil-contaminated soils $(0.220 \%$ and $14.10 \%)$ compared to those in the uncontaminated soils $(0.040 \%$ and $1.790 \%)$ were most probably due to crude oil contamination. Since the occurrence of total heterotrophic bacteria (THB) in soil can be used as an indicator for the extent of soil support to bacterial growth (Black et al. [5]), the THB were enumerated in soil samples before and after the addition of plant-derived materials. The counts of total heterotrophic bacteria (THB) and crude oil-degrading bacteria in soil samples after the addition of plant-derived materials increased significantly $(\mathrm{P}<0.05)$ where the counts of TBH in Conocarpus-amended soil $\left(585.4 \times 10^{3}-2985 \times 10^{3}\right.$ CFU $\mathrm{g}^{-1}$ soil) were significantly $(\mathrm{P}<0.05)$ higher than those in the Tamarixamended soil $\left(175.5 \times 10^{3}-1332 \times 10^{3} \mathrm{CFU} \mathrm{g}^{-1}\right.$ soil). This difference in THB counts indicated the higher supportive nature of Conocarpus-derived material to the growth of THB compared to that of Tamarix-derived material. Also, it was noticed that the addition of $20 \mathrm{mg} \mathrm{g}^{-1}$ soil of plant-derived materials to soil resulted in the significantly $(\mathrm{P}<0.05)$ higher increase in THB and crude oildegraders counts in Conocarpus- and Tamarix-amended soils compared to that when 60 and $100 \mathrm{mg} \mathrm{g}^{-1}$ soil of plant-derived materials were added to soil. These findings were in agreement with other studies (Al-Saleh and Obuekwe [2]; Obayori et al. [11]). The identification of the crude oil-degrading bacteria revealed the predominance of Gram-negative crude oil-degrading bacteria in the unamended and amended contaminated soil samples which might be due to the higher ability of Gram-negative bacteria to adapt to crude oil pollution. The identification of bacteria in the contaminated soil revealed the dominance of the genus Microbacterium (39.6\%), Sphingopyxis soli (19.3\%), and Bordetella petrii $(19.6 \%)$ in unamended, Conocarpus-amended and Tamarix-amended 
contaminated soils, respectively. The $16 \mathrm{~S}$ rRNA analyses of isolated crude oildegrading bacteria showed high diversity of isolated bacteria from the contaminated soil. Analysis of the distribution of band patterns of 16S-RFLP demonstrated the high diversity of isolated bacteria from the contaminated soil where the band-based similarity calculations revealed wide range of sequence differences among members of the same species. Therefore, the recycling of plant-derived materials could be an excellent option under conditions tested and confirm the commandments of sustainable planning.

\section{Acknowledgements}

We would like to acknowledge Kuwait University for funding this project. Z. Taqi is deeply grateful to Dr. Esmaeil Al-Saleh and Dr. Christian Obuekwe for their elaborate guidance and encouragement throughout the entire course of the work. Their patience and availability at all times is greatly appreciated.

Thanks also go to the lab colleagues for their help and support during the research.

\section{References}

[1] Alef K. (1995). Soil sampling, handling storage and analysis. In Methods in Applied Soil Microbiology and Biochemistry, pp. 49-116. Edited by K. Alef and P. Nannipieri. London: Academic Press, INC.

[2] Al-Saleh E.S. and Obuekwe C. (2005). Inhibition of hydrocarbon bioremediation by lead in a crude oil-contaminated soil. Inter. Biodeter. Biodeg., 56:1-7.

[3] Al-Saleh E., Drobiova H., and Obuekwe C. (2009). Predominant culturable crude oil-degrading bacteria in the cost of Kuwait. Inter. Biodeg. Biodeter., 63:400-406.

[4] Balonov M.I. (1997). Health impacts of large releases of radionuclides. Internal exposure of populations to long-lived radionuclides released into the environment. Ciba Found Symp., 203:133-140.

[5] Black H.I., Parekh N.R., Chaplow J.S., Monson F., Watkins J., Creamer R., Potter E.D., Poskitt J.M., Rowland P., Ainsworth G. and Hornung M. (2003). Assessing soil biodiversity across Great Britain: national trends in the occurrence of heterotrophic bacteria and invertebrates in soil. J. Environ. Manag., 67:255-66.

[6] Bragg J.R, Prince R.C., E. Harner E.J. and Atlas R.M. (1994). Effectiveness of bioremediation for the Exxon Valdez oil spill. Nature, 368:413-418.

[7] Civilini M., Domenis C., Sebastianutto N. and de Bertoldi M. (1997). Nicotine Decontamination of Tobacco Agro-Industrial Waste and Its Degradation by Micro-Organisms. Waste Manag. Res., 15:349-358.

[8] Edwards K.R., Lepo J.E. and Lewis M.A. (2003). Toxicity comparison of biosurfactants and synthetic surfactants used in oil spill remediation to two estuarine species. Mar. Poll. Bull., 46:1309-1316. 
186 Sustainability Today

[9] Lefebvre O. and Moletta R. (2006). Treatment of organic pollution in industrial saline wastewater: A literature review. Water Res., 40:3671-3682.

[10] Moss B. (2008). Water pollution by agriculture. Philos. Trans. R. Soc. Lond. B. Biol. Sci., 363: 659-666.

[11] Obayori O.S., Ilori M.O., Adebusoye S.A., Oyetibo G.O. and Amund O.O. (2008). Pyrene-degradation potentials of Pseudomonas species isolated from polluted tropical soils. World J. Microbiol. Biotechnol., 24:2639-2646.

[12] Xu R. and Obbard J. P. (2003). Effect of nutrient amendments on indigenous hydrocarbon biodegradation in oil-contaminated beach sediments. J. Environ. Qual., 32:1234-1243. 